Article

\title{
Volatile Secondary Metabolites with Potent Antidiabetic Activity from the Roots of Prangos pabularia Lind1.-Computational and Experimental Investigations
}

\author{
Sodik Numonov ${ }^{1,2,3}$, Farukh S. Sharopov $1,2,4 \oplus$, Sunbula Atolikhshoeva ${ }^{1}$, \\ Abduahad Safomuddin ${ }^{5}$, Mahinur Bakri ${ }^{1}$, William N. Setzer ${ }^{6,7}{ }^{\circ}$, Azizullo Musoev ${ }^{1}$, \\ Mizhgona Sharofova ${ }^{3}$, Maidina Habasi ${ }^{1,2, *}$ and Haji Akber Aisa 1,2,*(D) \\ 1 Key Laboratory of Plant Resources and Chemistry in Arid Regions, Xinjiang Technical Institute of Physics \\ and Chemistry, Chinese Academy of Sciences, Urumqi 830011, China; sodikjon82@gmail.com (S.N.); \\ shfarukh@mail.ru (F.S.S.); sunbula87@mail.ru (S.A.); mahinur@ms.xjb.ac.cn (M.B.); \\ azizullo.dr@gmail.com (A.M.) \\ 2 Research Institution “Chinese-Tajik Innovation Center for Natural Products", Ayni St. 299/2, \\ Dushanbe 734063, Tajikistan \\ 3 Center for Research in Innovative Technologies, Academy of Sciences of the Republic of Tajikistan, \\ Ayni St. 299/3, Dushanbe 734063, Tajikistan; mijgona72@mail.ru \\ 4 Department of Pharmaceutical Technology, Avicenna Tajik State Medical University, Rudaki 139, \\ Dushanbe 734003, Tajikistan \\ 5 Department of Chemistry, National University of Tajikistan, Rudaki 17/2, Dushanbe 734003, Tajikistan; \\ asafomuddin@rambler.ru \\ 6 Department of Chemistry, University of Alabama in Huntsville, Huntsville, AL 35899, USA; \\ wsetzer@chemistry.uah.edu \\ 7 Aromatic Plant Research Center, 230 N 1200 E, Suite 100, Lehi, UT 84043, USA \\ * Correspondence: maidn@ms.xjb.ac.cn (M.H.); haji@ms.xjb.ac.cn (H.A.A.); \\ Tel.: +86-991-3835679 (M.H. \& H.A.A.); Fax: +86-991-3838957 (M.H. \& H.A.A.)
}

Received: 14 May 2019; Accepted: 31 May 2019; Published: 10 June 2019

check for updates

\begin{abstract}
Background: Almost 500 million people worldwide are suffering from diabetes. Since ancient times, humans have used medicinal plants for the treatment of diabetes. Medicinal plants continue to serve as natural sources for the discovery of antidiabetic compounds. Prangos pabularia Lindl. is a widely distributed herb with large reserves in Tajikistan. Its roots and fruits have been used in Tajik traditional medicine. To our best knowledge, there are no previously published reports concerning the antidiabetic activity and the chemical composition of the essential oil obtained from roots of $P$. pabularia. (2) Methods: The volatile secondary metabolites were obtained by hydrodistillation from the underground parts of P. pabularia growing wild in Tajikistan and were analyzed by gas chromatography (GC) and gas chromatography-mass spectrometry (GC-MS). Protein tyrosine phosphatase 1B (PTP-1B) inhibition assay and molecular docking analysis were carried out to evaluate the potential antidiabetic activity of the P. pabularia essential oil. (3) Results: The main constituents of the volatile oil of P. pabularia were 5-pentylcyclohexa-1,3-diene (44.6\%), menthone (12.6\%), 1-tridecyne $(10.9 \%)$, and osthole $(6.0 \%)$. PTP-1B inhibition assay of the essential oil and osthole resulted in significant inhibitory activity with an $\mathrm{IC}_{50}$ value of $0.06 \pm 0.01$ and $0.93 \pm 0.1 \mu \mathrm{g} / \mathrm{mL}$. Molecular docking analysis suggests volatile compounds such as osthole inhibit PTP-1B, and the results are also in agreement with experimental investigations. (4) Conclusions: Volatile secondary metabolites and the pure isolated compound (osthole) from the roots of P. pabularia exhibited potent antidiabetic activity, twenty-five and nearly two times more than the positive control (3-(3,5-dibromo-4-hydroxybenzoyl)-2-ethylbenzofuran-6-sulfonic acid-(4-(thiazol-2-ylsulfamyl)-phenyl)-amide)) with an $\mathrm{IC}_{50}$ value of $1.46 \pm 0.4 \mu \mathrm{g} / \mathrm{mL}$, respectively.
\end{abstract}


Keywords: Prangos pabularia Lindl.; volatile oil; PTP-1B; osthole; 5-pentylcyclohexa-1,3-diene; antidiabetic activity

\section{Introduction}

Diabetes, or diabetes mellitus, is a chronic metabolic disease associated with high blood sugar levels over a prolonged period [1]. In 2017, according to the International Diabetes Federation report, approximately 425 million adults (20-79 years) had diabetes worldwide with 3.2 to 5.0 million deaths from the disease [2]. Unfortunately, these numbers are gradually increasing in most countries.

From ancient times, humans have used medicinal plants for the prevention and the therapy of diabetes mellitus. Medicinal plants serve as natural sources for the discovery of compounds with antidiabetic activities. In this relation, Tajikistan has a rich flora with around 4550 species of higher plants that represent great interest for the discovery of alternative medications for the treatment of diabetes [3]. Tajikistan is known for its diversity of environmental conditions, including climate, high altitudes, mountainous soil and minerals, and a relatively large number of sunny days per year, factors that can affect plant development as well as biosynthesis and accumulation of secondary metabolites $[4,5]$. Essential oils have applications in medicine, pharmaceutical, food, and cosmetic industries. They possess possible health benefits with antioxidant, antimicrobial, antitumor, anticarcinogenic, anti-inflammatory, anti-atherosclerosis, antimutagenic, antiplatelet aggregation, and angiogenesis-inhibitory activities. Therefore, extensive research has been directed toward the use of medicinal plants to control diabetes mellitus and its complications [6].

PTP-1B (protein-tyrosine phosphatase 1B) belongs to the protein tyrosine phosphatase (PTP) family. It is also known as tyrosine-protein phosphatase non-receptor type 1 that is encoded by the PTPN1 gene $[7,8]$. PTP-1B is localized on the cytoplasmic face of the endoplasmic reticulum and contains the essential catalytic cysteine [9]. The PTP-1B enzyme catalyzes the hydrolysis of phosphotyrosine from specific proteins [10]. PTP-1B is considered to be a promising potential therapeutic target for treatment of various diseases, including diabetes, obesity, and cancer [11]. It inactivates the insulin signal transduction cascade by dephosphorylating phosphotyrosine residues in the insulin-signaling pathway [12]. Natural, synthetic, as well as semi-synthetic compounds have shown prominent antidiabetic activities by inhibiting PTP-1B activity [13].

Prangos pabularia Lindl., a member of the Apiaceae, is a widely distributed herb up to $150 \mathrm{~cm}$ high with a thick cylindrical root and has large reserves in Tajikistan [14]. P. pabularia, locally known as "Yugan", is a well-known species of the genus in Tajikistan. It typically grows in mountainous areas and limestone slopes at altitudes 780 to $3600 \mathrm{~m}$ above sea level [15]. Its roots and fruits are valued in Tajik traditional medicine and are widely used as general tonics as well as for treatment of vitiligo $[4,15]$. P. pabularia has been used to treat leukoplakia, digestive disorders, scars, and bleeding [16]. The root extracts of P. pabularia have been examined for cytotoxic activity; the dichloromethane extract of P. pabularia roots demonstrated notable cytotoxicity on the HeLa carcinoma cell line [17]. P. ferulacea root is used as an effective wound healing agent in traditional medicine of the western north of Iran [18].

Members of the Prangos genus are natural sources of phytochemicals, including coumarins and terpenoids. Individual isolated pure compounds such as osthole and isoimperatorin showed the highest inhibitory potency against the growth of human carcinoma cell lines. Osthole exhibited the greatest cytotoxicity and was found to induce apoptosis in PC-3, H1299, and SKNMC cells at low micromolar concentrations. Thus, osthole can be considered to be a promising lead in anticancer drug discovery and development [17]. Several new compounds have been isolated from the essential oil of Prangos species. A new bisabolene derivative was isolated from essential oil of the fruits of Turkish endemic Prangos uechtritzii [19]. The 3,7(11)-Eudesmadien-2-one, a new eudesmane type sesquiterpene ketone was isolated from Prangos heyniae H. Duman \& M.F. Watson essential oil [20]. 
The (2S)-3,5-Nonadiyne-2-yl acetate was isolated from Prangos platychlaena ssp. platychlaena fruit essential oils [21].

Recently, we reported that the roots of P. pabularia are good sources of biologically active secondary metabolites (coumarins) such as heraclenol, heraclenin, imperatorin, osthole, yuganin A, and others. Yuganin A showed potent effects on the proliferation of B16 melanoma cells [22]. In a continuation of this investigation, the current report presents the promising antidiabetic activity and the chemical composition of volatile secondary metabolites of the underground parts of P. pabularia growing wild in Tajikistan. There are several reports on the composition of the essential oils isolated from leaves, fruits, and umbels of P. pabularia growing in Iran and Turkey [23-25], but, until now, there has been no published reports on antidiabetic activity and volatile secondary metabolites of the underground parts of P. pabularia.

\section{Results and Discussions}

\subsection{Chemical Composition of Essential Oils}

Volatile secondary metabolites were obtained by hydrodistillation of P. pabularia roots growing wild in Tajikistan and were analyzed by gas chromatography (GC) and gas chromatography-mass spectrometry (GC-MS). Identification of the oil components was based on their Kovats retention indices (RI) determined by reference to a homologous series of $n$-alkanes and by comparison of their mass spectral fragmentation patterns with those reported in the literature [26] and stored in the MS library. Forty-two compounds were identified in the volatile oil accounting for $97.3 \%$ of the composition; 5-Pentylcyclohexa-1,3-diene (44.6\%), menthone (12.6\%), 1-tridecyne (10.9\%), and osthole $(6.0 \%)$ were identified as major constituents of the volatile oil obtained from roots of P. pabularia (Table 1). The structure of the osthole was established on the basis one-dimensional (1D) NMR and electrospray ionization (ESI)-MS spectroscopic studies, respectively [22]. The chemical structures of the main components of the essential oil from the roots of P. pabularia are presented in Figure 1. The GC-MS chromatogram of the volatile oil of $P$. pabularia is presented in Figure 2.

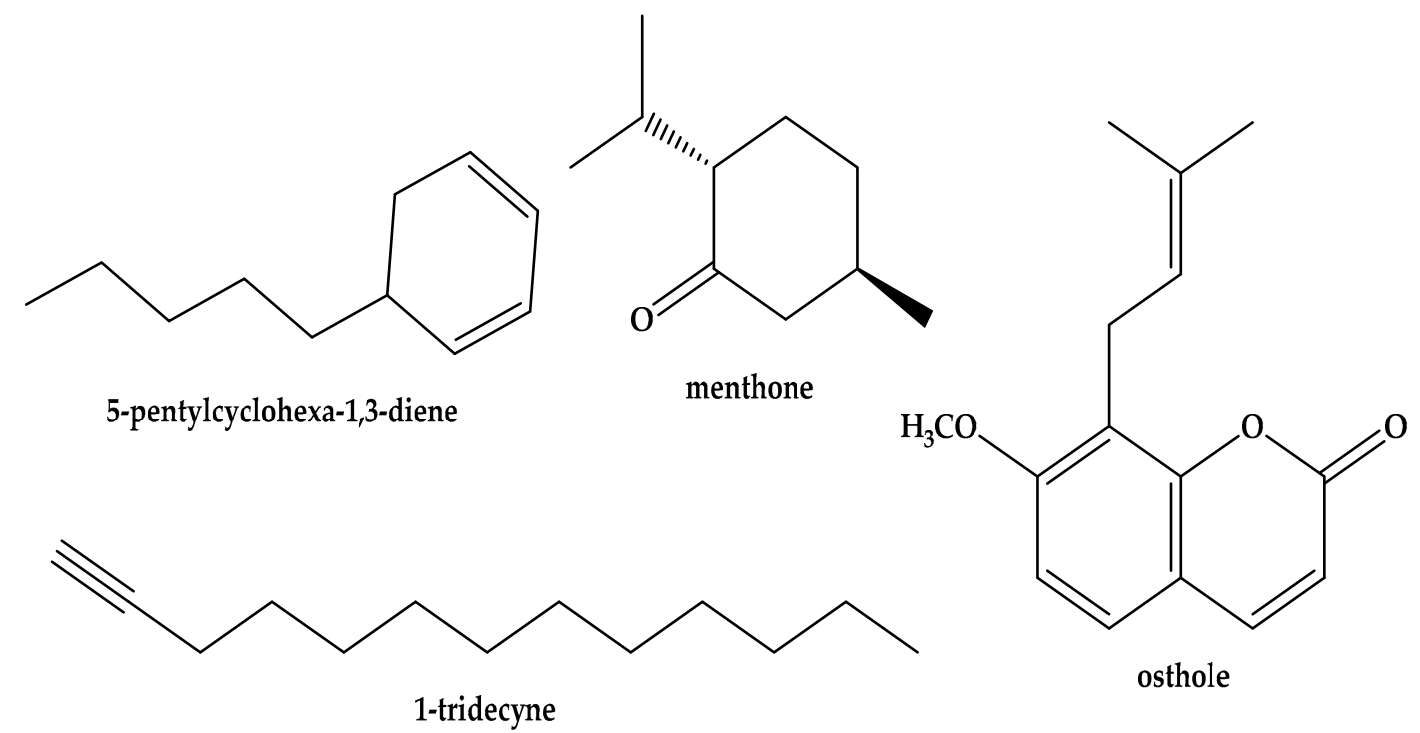

Figure 1. Structures of the main components of Prangos pabularia essential oil. 
Table 1. Chemical composition of the essential oil of the roots of Prangos pabularia growing wild in Tajikistan.

\begin{tabular}{|c|c|c|c|c|c|}
\hline RT & RI & Compound & MS & Fragmentations, $m / z(\%)$ & $\%$ \\
\hline 5.487 & 934 & (E)-1,3-Nonadiene & 124.13 & $67(100 \%) ; 54(82.37 \%) ; 124(41.49 \%) ; 68$ (36.07\%); 81 (35.96\%) & 1.5 \\
\hline 5.556 & 937 & 1-Nonen-4-yne & 122.11 & $79(100 \%) ; 77(49.67 \%) ; 78$ (21.32\%); 80 (19.82\%) & 0.8 \\
\hline 5.674 & 941 & $\alpha$-Pinene & 136.13 & $93(100 \%) ; 91(74.23 \%) ; 79$ (52.77\%); $77(51.98 \%) ; 92(42.0 \%)$ & 0.1 \\
\hline 6.006 & 953 & Camphene & 136.13 & $93(100 \%) ; 91(81.41 \%) ; 77$ (56.16\%); $79(54.03 \%) ; 92(31.5 \%)$ & $\operatorname{Tr}$ \\
\hline 6.106 & 957 & Propylbenzene & 120.09 & $91(100 \%) ; 65(18.7 \%) ; 120(17.78 \%) ; 92(10.48 \%) ; 78(8.87 \%)$ & 0.2 \\
\hline 6.162 & 959 & (3E)-2-Methylocten-5-yne & 122.11 & 79 (100\%); 91 (86.08\%); 77 (84.95\%); 93 (59.7\%); $122(35.51 \%)$ & 1.1 \\
\hline 6.656 & 977 & Sabinene & 136.14 & $93(100 \%) ; 77(69.92 \%) ; 79(68.13 \%) ; 91(58.51 \%) ; 53(30.37 \%)$ & 0.2 \\
\hline 6.974 & 989 & $\beta$-Pinene & 136.13 & $93(100 \%) ; 91(28.2 \%) ; 690(26.9 \%) ; 79$ (23.51\%); $77.1(22.1 \%)$ & 0.1 \\
\hline 7.068 & 993 & 3-Octanol & 130.14 & $59(100 \%) ; 83(81.4 \%) ; 55(78.3 \%) ; 101(29.96) ; 57(23.3 \%)$ & $\operatorname{Tr}$ \\
\hline 7.324 & 1002 & $\alpha$-Phellandrene & 136.13 & $93(100 \%) ; 122(84.73 \%) ; 91(81.47 \%) ; 79(75.95 \%) ; 107(52.5 \%)$ & 0.1 \\
\hline 7.468 & 1008 & $\delta$-3-Carene & 136.13 & $93(100 \%) ; 91(95.41 \%) ; 77(56.16 \%) ; 79(54.03 \%) ; 92(31.5 \%)$ & 0.1 \\
\hline 7.849 & 1022 & 1,9-Decadiyne & 134.11 & $79(100 \%) ; 77(52.95 \%) ; 67(51.87 \%) ; 91(49.70 \%) ; 81(37.7 \%)$ & 0.3 \\
\hline 7.943 & 1025 & Limonene & 136.13 & $93(100 \%) ; 68(80.91 \%) ; 67(80.89 \%) ; 79$ (80.07\%); 91 (73.16\%) & 0.4 \\
\hline 7.999 & 1027 & 1,8-Cineole & 154.14 & $81(100 \%) ; 111(90 \%) ; 67(87.77 \%) ; 108(87.37 \%) ; 55(85.72 \%)$ & 0.2 \\
\hline 8.162 & 1033 & (Z)- $\beta$-Ocimene & 136.13 & $93(100 \%) ; 91(86.50 \%) ; 79(63.32 \%) ; 77(43.30 \%) ; 92(36.2 \%)$ & 0.1 \\
\hline 8.437 & 1044 & $(E)$ - $\beta$-Ocimene & 136.13 & $93(100 \%) ; 91(86.50 \%) ; 79$ (63.32\%); $77(43.30 \%) ; 80(37.2 \%)$ & 0.1 \\
\hline 8.693 & 1053 & 5-Butylcyclohexa-1,3-diene & 136.13 & $79(100 \%) ; 91(84.32 \%) ; 77(79.63 \%) ; 93(49.2 \%) ; 136(36.48 \%)$ & 0.1 \\
\hline 11.399 & 1154 & Menthone & 154.14 & $112(100 \%) ; 55(77.25 \%) ; 69$ (69.36\%); 139 (44.49\%); 97 (34.09\%) & 12.6 \\
\hline 11.543 & 1160 & 5-Pentylcyclohexa-1,3-diene & 150.14 & $79(100 \%) ; 91(65.34 \%) ; 77(58.97 \%) ; 93(58.47 \%) ; 94(35.13 \%)$ & 44.6 \\
\hline 11.612 & 1162 & Viridene & 150.14 & $138(100 \%) ; 124(39.8 \%) ; 93(25.5 \%) ; 137(26.1)$ & 0.3 \\
\hline 11.649 & 1164 & iso-Menthone & 154.14 & $112(100 \%) ; 55$ (91.02\%); 69 (65.32\%); 95 (37.37\%); 139 (35.89\%) & 1.0 \\
\hline 11.831 & 1170 & 2-Methoxy-3-(1-methylpropyl)pyrazine & 166.11 & 138 (100\%); 124 (39.81\%); 151 (37.35\%); 93 (35.52\%); 137 (26.1\%) & 1.8 \\
\hline 11.974 & 1176 & neoiso-Pulegol & 150.14 & $67(100 \%) ; 55(73.02 \%) ; 53(62.77 \%) ; 69(56.57 \%) ; 79(53.38 \%)$ & 0.8 \\
\hline 13.449 & 1231 & Unidentified & - & $55(100 \%) ; 57(73.89 \%) ; 56(68.30 \%) ; 71(65.04 \%) ; 69(59.13 \%)$ & 1.7 \\
\hline 13.649 & 1239 & Pulegone & 152.12 & $81(100 \%) ; 67(93.29 \%) ; 109(57.3 \%) ; 152(48.89 \%) ; 82 .(38.27 \%)$ & 1.3 \\
\hline 13.731 & 1242 & Unidentified & - & $138(100 \%) ; 108(27.65 \%) ; 95(19.27 \%) ; 109(17.38 \%) ; 54(16.08 \%)$ & 0.7 \\
\hline 14.018 & 1252 & Unidentified & - & $138(100 \%) ; 108$ (35.28\%); 95 (27.12\%); 109 (15.38\%); 54 (10.2\%) & 0.2 \\
\hline 14.081 & 1255 & cis-Piperitone epoxide & 168.12 & $55(100 \%) ; 69(80.71 \%) ; 67(49.99 \%) ; 125(44.00 \%) ; 53(43.72 \%)$ & 1.3 \\
\hline 14.118 & 1256 & (4Z)-Decen-1-ol & 156.15 & $55(100 \%) ; 70(64.85 \%) ; 69(62.42 \%) ; 56(57.42 \%) ; 83(49.55 \%)$ & 0.5 \\
\hline 14.543 & 1272 & 1-Decanol & 158.17 & $55(100 \%) ; 70(64.85 \%) ; 69(62.42 \%) ; 56(57.42 \%) ; 83(49.55 \%)$ & 2.0 \\
\hline 15.299 & 1300 & 1-Tridecyne & 180.19 & $81(100 \%) ; 55(79.41 \%) ; 67(78.15 \%) ; 69(47.9 \%) ; 68(40.50 \%)$ & 10.9 \\
\hline 17.012 & 1365 & Piperitenone oxide & 166.10 & $67(100 \%) ; 138(63.48 \%) ; 68(62.28 \%) ; 53(38.29 \%) ; 79(36.54 \%)$ & 0.7 \\
\hline 17.143 & 1371 & 1-Undecanol & 172.18 & $55(100 \%) ; 69(73.24 \%) ; 56(61.43 \%) ; 83(55.86 \%) ; 70(49.46 \%)$ & 0.3 \\
\hline
\end{tabular}


Table 1. Cont.

\begin{tabular}{|c|c|c|c|c|c|}
\hline RT & RI & Compound & MS & Fragmentations, $m / z(\%)$ & $\%$ \\
\hline 17.868 & 1399 & 3-Dodecyn-2-ol & 182.17 & 55 (100\%); 67 (99.69\%); 69 (76.48\%); 95 (72.69\%); 68 (56.92\%) & 2.1 \\
\hline 18.237 & 1414 & $\beta$-Longipinene & 190.17 & 91 (100\%); 77 (72.64\%); 93 (62.14\%); 161 (58.85\%); 105 (57.88\%) & 0.6 \\
\hline 18.406 & 1421 & $\beta$-Caryophyllene & 204.19 & $91(100 \%) ; 79(86.59 \%) ; 93(67.92 \%) ; 77(66.1 \%) ; 105(55.12 \%)$ & 1.0 \\
\hline 18.718 & 1433 & $\gamma$-Elemene & 204.19 & $121(100 \%) ; 177(98.85 \%) ; 91$ (58.5\%); $93(57.4 \%) ; 107(43.1 \%)$ & 0.1 \\
\hline 18.781 & 1436 & trans- $\alpha$-Bergamotene & 204.19 & $93(100 \%) ; 91(80.84 \%) ; 119(75.05 \%) ; 77(57.71 \%) ; 69(48.76 \%)$ & 1.6 \\
\hline 19.331 & 1459 & (7Z)-Dodecen-1-ol & 184.18 & $67(100 \%) ; 55(62.01 \%) ; 81(56.91 \%) ; 54$ (49.91\%); $82(47.42 \%)$ & 0.2 \\
\hline 19.768 & 1477 & $\gamma$-Gurjunene & 204.19 & $91(100 \%) ; 77(87.25 \%) ; 79(83.86 \%) ; 93(79.86 \%) ; 161(76.27 \%)$ & 0.1 \\
\hline 20.056 & 1489 & $\beta$-Selinene & 204.19 & $79(100 \%) ; 91(75.67 \%) ; 67(75.38 \%) ; 93(63.4 \%) ; 105(61.85 \%)$ & 0.5 \\
\hline 20.193 & 1494 & $(3 Z, 6 E)-\alpha$-Farnesene & 204.19 & 119 (100\%); 91 (69.2\%); 79 (60.9\%); $81(58.5 \%) ; 77$ (55.6\%) & 0.5 \\
\hline 20.231 & 1496 & Valencene & 204.19 & $91(100 \%) ; 79$ (97.61\%); $105(83.71 \%) ; 93(80.93 \%) ; 77(75.81 \%)$ & 0.8 \\
\hline 20.274 & 1498 & $\alpha$-Selinene & 204.19 & $93(100 \%) ; 91$ (83.3\%); 69 (68.3\%); 105 (50.3\%); 77 (49.2\%) & 0.3 \\
\hline \multirow[t]{7}{*}{33.581} & 2141 & Osthole & 244.11 & $244(100 \%) ; 201$ (93.94\%); 229 (93.95\%); $131(65.60 \%) ; 189(63.98 \%)$ & 6.0 \\
\hline & & Monoterpene hydrocarbons & & & 1.3 \\
\hline & & Oxygenated monoterpenoids & & & 17.8 \\
\hline & & Sesquiterpene hydrocarbons & & & 5.5 \\
\hline & & Fatty acid derived & & & 19.8 \\
\hline & & Others & & & 53.0 \\
\hline & & Total Identified & & & 97.3 \\
\hline
\end{tabular}

${ }^{*} \mathrm{RI}$ : retention indices. 


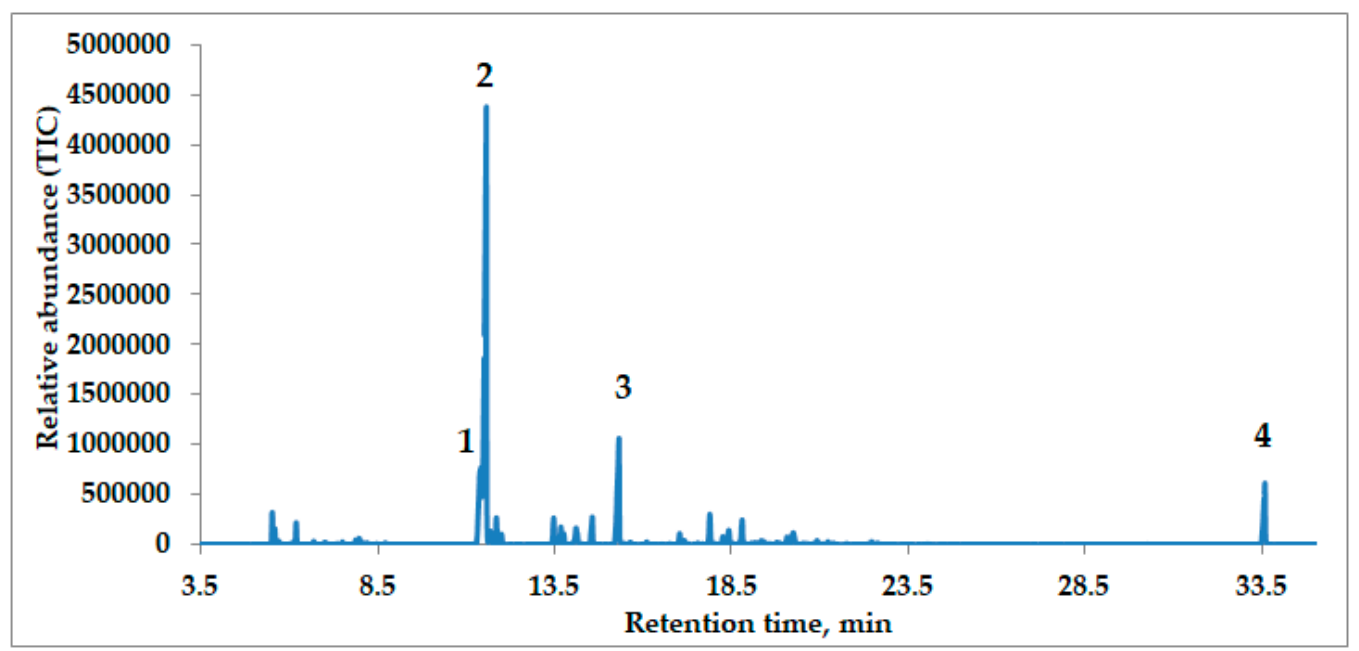

Figure 2. The GC-MS chromatogram of the volatile oil of Prangos pabularia. 1. menthone; 2. 5-pentylcyclohexa-1,3-diene; 3. 1-tridecyne; 4. osthole.

\subsection{NMR Data of Osthole}

${ }^{1} \mathrm{H}$ NMR $\left(400 \mathrm{MHz}, \mathrm{CDCl}_{3}\right): \delta 6.23(1 \mathrm{H}, \mathrm{d}, J=9.4 \mathrm{~Hz}, \mathrm{H}-3), 7.61(1 \mathrm{H}, \mathrm{d}, J=9.4 \mathrm{~Hz}, \mathrm{H}-4), 7.28(1 \mathrm{H}, \mathrm{d}$, $J=8.6 \mathrm{~Hz}, \mathrm{H}-5), 6.83(1 \mathrm{H}, \mathrm{d}, J=8.6 \mathrm{~Hz}, \mathrm{H}-6), 3.53(1 \mathrm{H}, \mathrm{d}, J=7.3 \mathrm{~Hz}, \mathrm{H}-11), 5.22(1 \mathrm{H}, \mathrm{m}, \mathrm{H}-12), 1.67(3 \mathrm{H}$, s, H-14), 1.84 (3H, s, H-115), $3.92(3 \mathrm{H}, \mathrm{s}, \mathrm{OCH}-7) ;{ }^{13} \mathrm{C}$ NMR $\left(100 \mathrm{MHz}, \mathrm{CDCl}_{3}\right): \delta 161.49$ (C-2), 113.11 (C-3), 143.87 (C-4), 126.32 (C-5), 107.47 (C-6), 160.34 (C-7), 118.10 (C-8), 152.95 (C-9), 113.14 (C-10), 22.06 (C-11), 121.25 (C-12), 132.75 (C-13), 18.06 (C-14), 25.91 (C-15), 56.17 (OCH3-7).

Acorenone, $(E)$-anethol, $\beta$-bisabolenal, $\beta$-bisabolenol, $\beta$-bisabolene, bicyclogermacrene, $\delta$-3-carene, chrysanthenyl acetate, $\beta$-caryophyllene, elemol, 3,7(11)-eudesmadien-2-one, geranial, germacrene $D$, $\alpha$-humulene, kessane, limonene, $p$-menth-3-ene, nerolidol, $(Z)$ - $\beta$-ocimene, $(E)$ - $\beta$-ocimene, $\alpha$-pinene, $\beta$-pinene, $\alpha$-phellandrene, $\beta$-phellandrene, sabinene, $\gamma$-terpinene, $\alpha$-terpinolene, $m$-tolualdehyde, and 2,3,6-trimethyl benzaldehyde were reported as major components $(\geq 10 \%)$ in the essential oil of Prangos species (Table 2).

Table 2. The major compounds reported as chemical composition of essential oil from Prangos species.

\begin{tabular}{|c|c|c|c|}
\hline Prangos Species & Plant Part & Major Components of the Essential Oil & Ref. \\
\hline P. acaulis & aerial parts & $\begin{array}{l}\delta \text {-3-carene }(25.5 \%), \alpha \text {-terpinolene }(14.8 \%), \alpha \text {-pinene }(13.6 \%), \text { limonene } \\
(12.9 \%) \text {, myrcene }(8.1 \%)\end{array}$ & [27] \\
\hline P. asperula & fruits & $\begin{array}{l}\delta \text {-3-carene }(16.1 \%), \beta \text {-phellandrene }(14.7 \%), \alpha \text {-pinene }(10.5 \%), \alpha \text {-humulene } \\
(7.8 \%) \text {, germacrene- } \mathrm{D}(5.4 \%)\end{array}$ & [28] \\
\hline P. asperula & $\begin{array}{l}\text { fresh aerial } \\
\quad \text { parts }\end{array}$ & $\begin{array}{l}\text { sabinene }(43.5 \%), \beta \text {-phellandrene }(36.1 \%),(E) \text {-nerolidol }(15.2 \%) \text {, } \\
p \text {-menth-3-ene }(14.9 \%),(E) \text {-nerolidol }(14.7 \%), p \text {-menth-3-ene }(13.3 \%) \text { in stem } \\
\text { and leaves, } \alpha \text {-phellandrene }(11.9 \%) \text { in fruits, } \beta \text {-myrcene }(9.2 \%) \text { in stem and } \\
\text { leaves; } \alpha \text {-terpinene }(8.3 \%) \text { in fruits, } \beta \text {-phellandrene }(7.9 \%) \text { in flowers }\end{array}$ & [29] \\
\hline P. asperula & aerial parts & $\begin{array}{l}\text { 2,3,6-trimethyl benzaldehyde (18.4\%), } \delta \text {-3-carene }(18.0 \%) \text { and } \alpha \text {-pinene } \\
(17.4 \%)\end{array}$ & [30] \\
\hline P. asperula & fruit & sabinene $(43.5 \%)$ & [31] \\
\hline P. ferulacea & fruits & $\begin{array}{l}\alpha \text {-pinene }(57 \%) \text { (vegetative stage), } \gamma \text {-terpinene (30.2-33.3\%) and } \alpha \text {-pinene } \\
(16.7-12.8 \%)\end{array}$ & [32] \\
\hline P. ferulacea & aerial parts & (E)-anethol (95.5\%) (flowering stage) & [16] \\
\hline P. ferulacea & fruits & chrysanthenyl acetate $(26.5 \%)$, limonene $(19.6 \%), \alpha$-pinene $(19.5 \%)$ & [33] \\
\hline P. ferulacea & aerial parts & $\beta$-pinene $(43.1 \%), \alpha$-pinene $(22.1 \%)$ and $\delta$-3-carene $(16.9 \%)$ & [34] \\
\hline P. ferulacea & aerial parts & 2,3,6-trimethyl benzaldehyde (66.6\%) & [35] \\
\hline
\end{tabular}


Table 2. Cont.

\begin{tabular}{|c|c|c|c|}
\hline Prangos Species & Plant Part & Major Components of the Essential Oil & Ref \\
\hline P. ferulacea & aerial parts & $\beta$-caryophyllene (48.2\%), $\alpha$-humulene (10.3\%) and spathulenol $(9.4 \%)$ & [36] \\
\hline P. ferulacea & aerial parts & $\alpha$-pinene $(36.6 \%)$ and $\beta$-pinene $(31.1 \%)$ & [37] \\
\hline P. ferulacea & roots & $\beta$-phellandrene (32.1\%), $m$-tolualdehyde $(26.2 \%)$, and $\delta$-3-carene $(25.8 \%)$ & [18] \\
\hline P. ferulaceae & $\begin{array}{l}\text { fruits and } \\
\text { umbels }\end{array}$ & $\alpha$-pinene and (Z)- $\beta$-ocimene & [38] \\
\hline P. heyniae & fruits & $\begin{array}{l}\beta \text {-bisabolenal (18.0-53.3\%), } \beta \text {-bisabolenol (2.3-14.6\%) and } \beta \text {-bisabolene } \\
(10.1-12.1 \%)\end{array}$ & [39] \\
\hline P. heyniae & aerial parts & $\begin{array}{l}\beta \text {-bisabolenal }(1.4-70.7 \%),(8.2 \%) \text {, elemol }(3.4-46.9 \%), \text { kessane }(26.9 \%) \text {, } \\
\beta \text {-bisabolene }(14.4 \%) \text {, germacrene D }(10.3-12.1 \%) \text {, germacrene B } \\
\text { 3,7(11)-eudesmadien-2-one }(16.1 \%) \text { and } \beta \text {-bisabolenol }(8.4 \%)\end{array}$ & {$[20]$} \\
\hline P. latiloba & aerial parts & geranial $(26.8 \%)$ & [31] \\
\hline P. pabularia & $\begin{array}{l}\text { flowering } \\
\text { aerial parts }\end{array}$ & $\begin{array}{l}\alpha \text {-pinene }(32.4 \%), \delta \text {-3-carene }(12.4 \%) \text {, germacrene D }(8.1 \%) \text {, limonene }(6.4 \%) \\
\text { and bicyclogermacrene }(6.2 \%)\end{array}$ & [40] \\
\hline P. pabularia & fruit & $\begin{array}{l}\text { bicyclogermacrene }(21 \%),(Z)-\beta \text {-ocimene }(19 \%), \alpha \text {-humulene }(8 \%), \alpha \text {-pinene } \\
(8 \%) \text {, spathulenol }(6 \%) \text {, suberosin }(2 \%)\end{array}$ & {$[24]$} \\
\hline P. peucedanifolia & $\begin{array}{l}\text { flowering } \\
\text { aerial parts }\end{array}$ & $\alpha$-pinene $(38.1 \%)$, bicyclogermacrene $(11.3 \%)$ and $\delta$-3-carene $(9.2 \%)$ & [40] \\
\hline P. uloptera & aerial parts & $\delta$-3-carene (26.3\%), $\alpha$-pinene (15.4\%), $\beta$-myrcene (9.0\%), $p$-cymene $(8.6 \%)$ & [41] \\
\hline P. uloptera & aerial parts & $\beta$-caryophyllene (18.2\%), germacrene D (17.2\%) and limonene $(8.7 \%)$ & [42] \\
\hline P. uloptera & seed & $\alpha$-pinene $(41.9 \%)$ and $\beta$-cedrene $(4.0 \%)$ & [42] \\
\hline P. uloptera & aerial parts & $\begin{array}{l}\alpha \text {-pinene }(20.3 \%),(E) \text { - } \beta \text {-ocimene }(19.6 \%), \beta \text {-caryophyllene in fresh aerial } \\
\text { parts; } \beta \text {-caryophyllene }(13.9 \%), \alpha \text {-pinene }(13.6 \%) \text {, caryophyllene-oxide } \\
(11.6 \%) \text { in dried aerial parts; }(9.9 \%), \delta \text {-3-carene }(8.0 \%) \text {, germacrene D }(6.0 \%) \\
\text { in fresh aerial parts; spathulenol }(7.8 \%) \text { and germacrene D }(4.7 \%) \text { in dried } \\
\text { aerial parts }\end{array}$ & [43] \\
\hline P. uloptera & fruits & $\begin{array}{l}\text { germacrene D }(17.6 \%) \text {, acorenone }(16.9 \%), \alpha \text {-pinene }(14.9 \%) \text {, and } \alpha \text {-humulene } \\
(8.2 \%)\end{array}$ & [44] \\
\hline
\end{tabular}

Razavi reported that the composition of the essential oils isolated from leaves, fruits, and umbels of $P$. pabularia collected from Iran were dominated by spathulenol, $\alpha$-bisabolol, and $\alpha$-pinene [25]. Bicyclogermacrene, $(Z)$ - $\beta$-ocimene, $\alpha$-humulene, $\alpha$-pinene, and spathulenol were reported as the main constituents of the essential oil of P. pabularia fruits collected from Turkey [24]. The chemical composition of the root essential oil of P. pabularia differed from those from leaves, fruits, and umbels with regard to predominance of sesquiterpenes and monoterpenes. In 2016, Tabanca and co-authors reported that suberosin $(1.8 \%)$ was identified in the essential oil obtained from fruits of $P$. pabularia. In present work, 5-pentylcyclohexa-1,3-diene (44.6\%), menthone (12.6\%), 1-tridecyne (10.9\%), and osthole (6\%) (an isomer of suberosin) were identified as the dominant constituents of the volatile oil of the roots of P. pabularia. These major volatile compounds were not identified from the other Prangos species (Table 2). Therefore, it confirms the different chemical composition from P. pabularia. Recently, we reported that osthole was isolated from the chloroform extract of the roots of $P$. pabularia, and its structure was elucidated by spectroscopic means, namely, high resolution electrospray ionisation mass spectrometry (HR-ESIMS) and one-dimensional (1D) and two-dimensional (2D) nuclear magnetic resonance (NMR) spectroscopy [22]. In addition, osthole was isolated from the hexane extract of the fruits of P. asperula [30].

Both osthole and suberosin were found in Arracacia tolucensis var. multifida volatile oil [45]. The essential oil with the high coumarin content showed moderate in-vitro antibacterial activity against representative Gram-positive and Gram-negative bacteria [45]. 


\subsection{Antidiabetic Activity of Essential Oil and Isolated Compound (Osthole)}

The effect of the obtained essential oil and the pure compound (osthole) from P. pabularia roots for its in vitro inhibition of the enzyme PTP-1B was determined. The essential oil induced a PTP-1B enzymatic inhibition in a concentration-dependent manner with $\mathrm{IC}_{50}$ values $0.06 \pm 0.01 \mu \mathrm{g} / \mathrm{mL}(p<0.02)$, which is more than 25 times more potent than the positive control (3-(3,5-dibromo-4-hydroxybenzoyl)-2-ethylbenzofuran-6-sulfonic acid-(4-(thiazol-2-ylsulfamyl)phenyl)-amide) with $\mathrm{IC}_{50} 1.46 \pm 0.4 \mu \mathrm{g} / \mathrm{mL}(p<0.05)$. The individual compound (osthole) also exhibited strong inhibitory activity against PTP-1B, with $\mathrm{IC}_{50}$ values $0.93 \pm 0.1 \mu \mathrm{g} / \mathrm{mL}(p<0.01)$; it was also more effective than the positive control. The dose response curves of the inhibition of the PTP-1B enzyme of P. pabularia essential oil and osthole are shown in Figure 3.

Wang and co-authors presented a strategy based on GC-MS coupled with molecular docking for analysis, identification, and prediction of PTP-1B inhibitors in the Himalayan cedar essential oil. $\beta$-Pinene (49.3\%), $\alpha$-pinene (29.4\%), $\alpha$-terpineol (4.1\%), and $\beta$-caryophyllene (3.7\%) were the main components of Himalayan cedar oil that inhibited PTP-1B with $\mathrm{IC}_{50}$ value $120.71 \pm 0.26 \mu \mathrm{g} / \mathrm{mL}$. The docking results of the PTP-1B inhibitory activity of caryophyllene oxide was also in agreement with its in vitro activity [46]. The $\mathrm{IC}_{50}$ value for PTP-1B inhibition for caryophyllene oxide was in the range 25.8-31.3 $\mu \mathrm{M}[46,47]$. New terpenoids cedrodorols A-B from Cedrela odorata showed inhibitory PTP-1B activity with IC 50 values 13.09 and $3.93 \mu \mathrm{g} / \mathrm{mL}$, respectively [48]. In another study, Bharti and co-authors reported the in vivo antidiabetic activity of Cymbopogon citratus essential oil with major compounds, geranial (42.4\%), neral (29.8\%), myrcene $(8.9 \%)$, and geraniol $(8.5 \%)$, which were fully supported by molecular docking predictions [49].
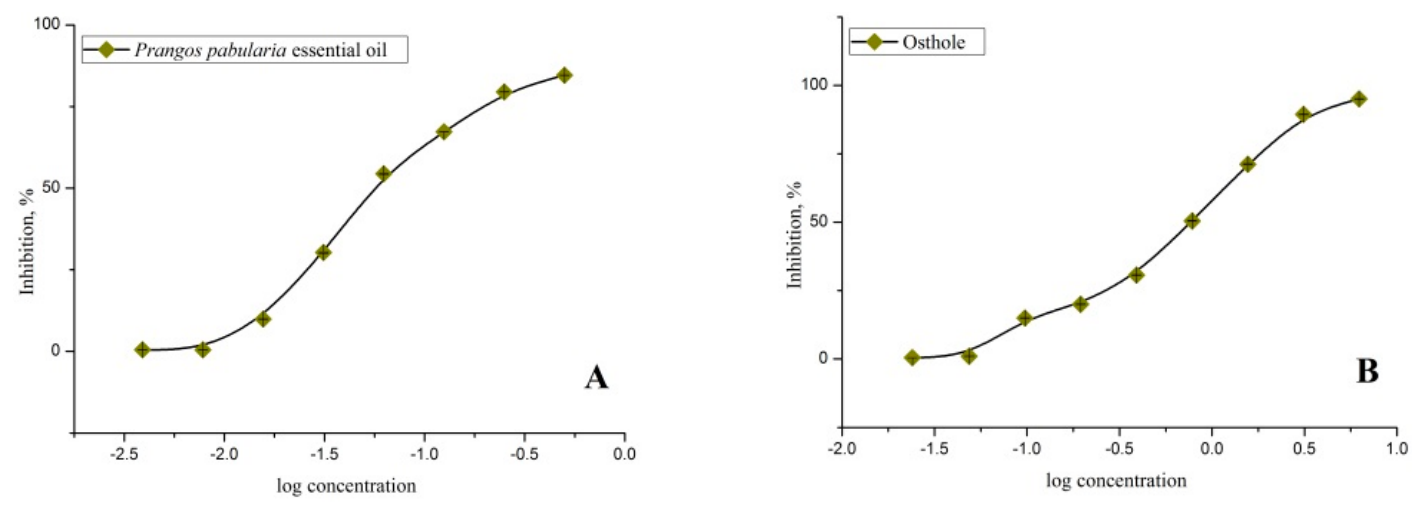

Figure 3. Dose response curve of inhibition of protein-tyrosine phosphatase 1B (PTP-1B) enzyme for Prangos pabularia essential oil (A) $\left(\mathrm{IC}_{50}=0.06 \pm 0.01 \mu \mathrm{g} / \mathrm{mL}\right)$ and the pure compound osthole (B) $\left(\mathrm{IC}_{50}=0.93 \pm 0.01 \mu \mathrm{g} / \mathrm{mL}\right)$.

Hong-Jen Liang investigated the hypoglycemic effects of osthole in diabetic $\mathrm{db} / \mathrm{db}$ mice, and the main mechanisms of these effects were elucidated using an in vitro cell-based assay and in vivo assays using a diabetic $\mathrm{db} / \mathrm{db}$ mouse model. Results showed that osthole significantly alleviated hyperglycemia by activating PPAR $\alpha / \gamma$ in a dose-dependent manner based on the results of the transition transfection assay $[50,51]$. Wei-Hwa Lee reported that the western blot analysis revealed osthole to significantly induce phosphorylation of AMP-activated protein kinase (AMPK) and acetyl-CoA carboxylase (ACC) as well as increase translocation of glucose transporter 4 (GLUT4) to plasma membranes and glucose uptake in a dose-dependent manner [50]. These results suggest that the increase in the AMP:ATP ratio by osthole had triggered activation of the AMPK signaling pathway, leading to increases in plasma membrane GLUT4 concentration and glucose uptake level [52]. Other research has clearly shown that osthole lowered fasting blood glucose (FBG) and improved insulin secretion. This may indicate partial recovery from pancreatic damage, as indicated from histological characteristics [53]. 


\subsection{Molecular Docking}

A molecular docking analysis was carried out on the 12 most abundant components from the root essential oil of P. pabularia using the Molegro Virtual Docker program [54]. The MolDock "rerank" docking energies as well as the scaled molecular docking energies are summarized in Table 3 . There are two ligand binding regions in human PTP-1B - the catalytic site and an allosteric site (Figure 4). Nearly all of the ligands examined docked preferentially to the allosteric binding site in PDB 1T48, and the best docking ligand was osthole. In the allosteric binding site, the coumarin rings are located in a hydrophobic sandwich formed by Phe280 and Leu192 (Figure 5). Additionally, the aromatic residues Trp291 and Phe196 form face-to-edge $\pi$ interactions with the coumarin moiety. Residues Ala189 and Glu276 surround the isopropylidene group of osthole. There are no apparent hydrogen-bonding interactions in the docked osthole in the allosteric binding site.

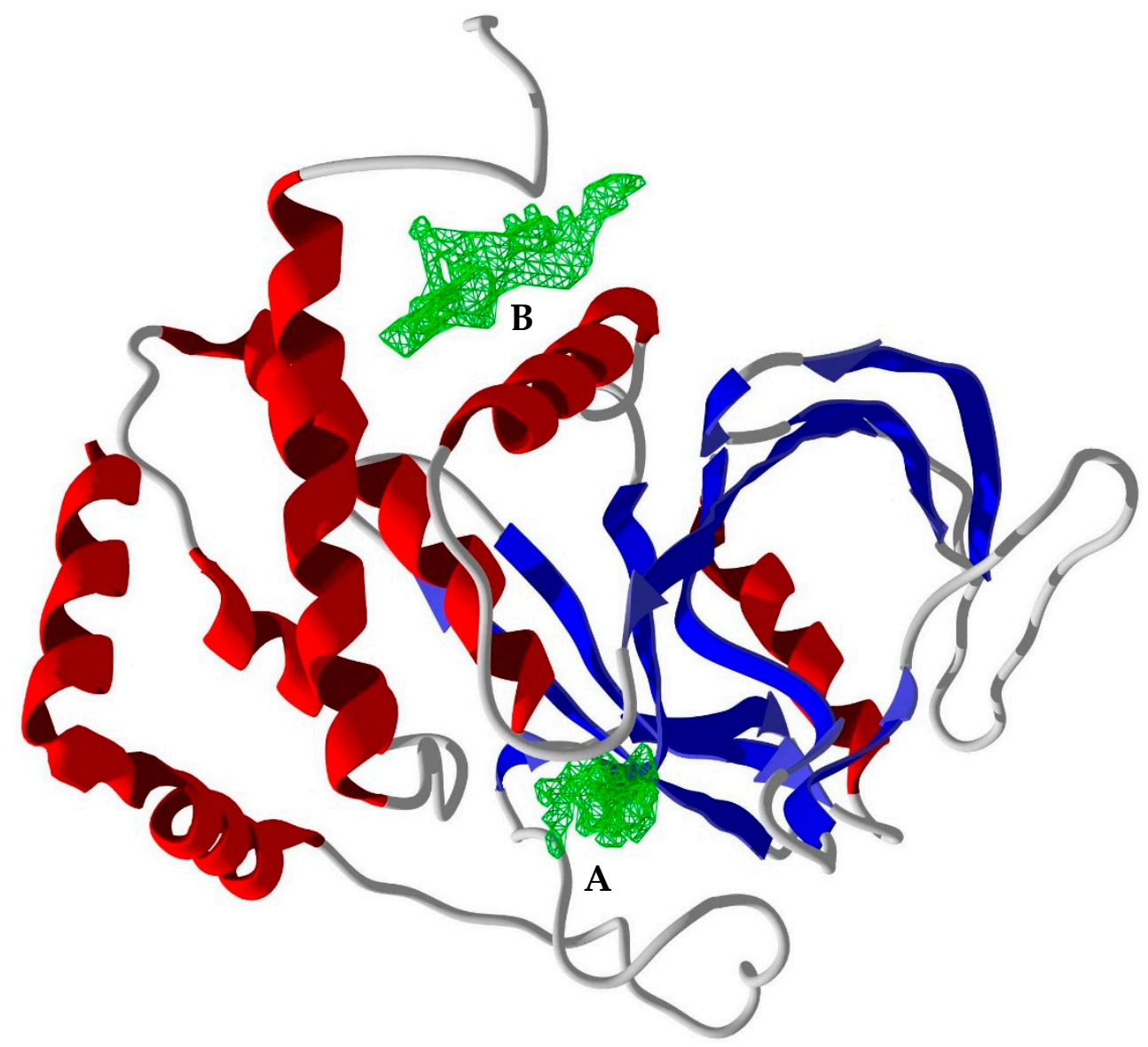

Figure 4. Ribbon structure of human protein tyrosine phosphatase 1B (PTP-1B, PDB 1T48). The catalytic site (A) and the allosteric binding site (B) are shown as green cross-hatched areas.

The active site of PTP-1B is composed of highly polar residues, including Arg24, Lys41, Arg47, and Asp48, as well as the phosphate-binding loop, Cys215-Arg22 [55]. Therefore, the active site of PTP-1B is not a likely target for the hydrophobic essential oil components of P. pabularia. Nevertheless, the lowest-energy docked pose of osthole with the active site of PTP-1B (PDB 2HB1) has a scaled docking energy of $-103.0 \mathrm{~kJ} / \mathrm{mol}$. This docking pose of osthole shows $\pi$-stacking of the coumarin moiety with Phe182 and Tyr46 and is held close to the catalytic site residues of Cys215 and Arg221 (Figure 6). In addition, there are hydrogen-bonding interactions between the osthole carbonyl oxygen and the side chains of Lys120 and Arg221. 
Table 3. MolDock "rerank" docking energies (kJ/mol) and molecular-weight-scaled docking energies (in parentheses) for Prangos pabularia root essential oil major components with human PTP-1B.

\begin{tabular}{|c|c|c|c|c|c|c|c|}
\hline & $1 \mathrm{~T} 48$ & $1 \mathrm{~T} 49$ & 2BGE & 2CMB & 2 F71 & $2 \mathrm{HB} 1$ & $3 C W E$ \\
\hline Ligand & Allosteric Site & Allosteric Site & Active Site & Active Site & Active Site & Active Site & Active Site \\
\hline (3E)-2-Methylocten-5-yne & $\begin{array}{l}-64.6 \\
(-93.9)\end{array}$ & $\begin{array}{l}-60.2 \\
(-87.4)\end{array}$ & $\begin{array}{l}-62.5 \\
(-90.8)\end{array}$ & $\begin{array}{l}-61.1 \\
(-88.7)\end{array}$ & $\begin{array}{l}-60.0 \\
(-87.2)\end{array}$ & $\begin{array}{l}-57.8 \\
(-84.1)\end{array}$ & $\begin{array}{l}-62.0 \\
(-90.1)\end{array}$ \\
\hline (E)-1,3-Nonadiene & $\begin{array}{l}-67.8 \\
(-97.9)\end{array}$ & $\begin{array}{l}-58.5 \\
(-84.5)\end{array}$ & $\begin{array}{l}-63.0 \\
(-91.1)\end{array}$ & $\begin{array}{l}-63.5 \\
(-91.8)\end{array}$ & $\begin{array}{l}-65.9 \\
(-95.2)\end{array}$ & $\begin{array}{l}-62.2 \\
(-89.9)\end{array}$ & $\begin{array}{l}-64.1 \\
(-92.7)\end{array}$ \\
\hline 1-Decanol & $\begin{array}{c}-76.5 \\
(-102.0)\end{array}$ & $\begin{array}{l}-66.8 \\
(-89.0)\end{array}$ & $\begin{array}{l}-71.0 \\
(-94.6)\end{array}$ & $\begin{array}{l}-73.0 \\
(-97.4)\end{array}$ & $\begin{array}{l}-72.7 \\
(-96.9)\end{array}$ & $\begin{array}{l}-69.8 \\
(-93.1)\end{array}$ & $\begin{array}{l}-70.4 \\
(-93.9)\end{array}$ \\
\hline 1-Tridecyne & $\begin{array}{c}-86.4 \\
(-110.4)\end{array}$ & $\begin{array}{l}-72.7 \\
(-92.8)\end{array}$ & $\begin{array}{l}-73.2 \\
(-93.4)\end{array}$ & $\begin{array}{c}-79.0 \\
(-100.9)\end{array}$ & $\begin{array}{l}-76.7 \\
(-97.9)\end{array}$ & $\begin{array}{l}-71.8 \\
(-91.6)\end{array}$ & $\begin{array}{l}-73.4 \\
(-93.7)\end{array}$ \\
\hline 2-Methoxy-3-(1-methylpropyl)pyrazine & $\begin{array}{c}-76.5 \\
(-100.4)\end{array}$ & $\begin{array}{l}-64.3 \\
(-84.4)\end{array}$ & $\begin{array}{l}-65.6 \\
(-86.0)\end{array}$ & $\begin{array}{l}-66.2 \\
(-86.8)\end{array}$ & $\begin{array}{l}-62.9 \\
(-82.5)\end{array}$ & $\begin{array}{l}-66.0 \\
(-86.5)\end{array}$ & $\begin{array}{l}-71.7 \\
(-94.0)\end{array}$ \\
\hline 3-Dodecyn-2-ol & $\begin{array}{c}-84.2 \\
(-107.1)\end{array}$ & $\begin{array}{l}-72.4 \\
(-92.1)\end{array}$ & $\begin{array}{c}-79.2 \\
(-100.8)\end{array}$ & $\begin{array}{l}-74.2 \\
(-94.4)\end{array}$ & $\begin{array}{c}-80.5 \\
(-102.4)\end{array}$ & $\begin{array}{l}-77.3 \\
(-98.3)\end{array}$ & $\begin{array}{l}-77.4 \\
(-98.4)\end{array}$ \\
\hline 5-Pentyl-1,3-cyclohexadiene & $\begin{array}{l}-72.3 \\
(-98.1)\end{array}$ & $\begin{array}{l}-66.2 \\
(-89.9)\end{array}$ & $\begin{array}{l}-70.7 \\
(-95.9)\end{array}$ & $\begin{array}{l}-68.9 \\
(-93.5)\end{array}$ & $\begin{array}{l}-68.5 \\
(-92.9)\end{array}$ & $\begin{array}{l}-67.8 \\
(-92.0)\end{array}$ & $\begin{array}{l}-68.7 \\
(-93.2)\end{array}$ \\
\hline cis-Piperitone epoxide & $\begin{array}{l}-76.0 \\
(-99.3)\end{array}$ & $\begin{array}{l}-65.5 \\
(-85.6)\end{array}$ & $\begin{array}{l}-65.8 \\
(-86.0)\end{array}$ & $\begin{array}{l}-67.4 \\
(-88.1)\end{array}$ & $\begin{array}{l}-69.0 \\
(-90.2)\end{array}$ & $\begin{array}{l}-73.1 \\
(-95.4)\end{array}$ & $\begin{array}{l}-75.0 \\
(-98.0)\end{array}$ \\
\hline Menthone & $\begin{array}{l}-72.3 \\
(-97.2)\end{array}$ & $\begin{array}{l}-60.6 \\
(-81.5)\end{array}$ & $\begin{array}{l}-59.0 \\
(-79.3)\end{array}$ & $\begin{array}{l}-55.2 \\
(-74.2)\end{array}$ & $\begin{array}{l}-59.7 \\
(-80.3)\end{array}$ & $\begin{array}{l}-65.6 \\
(-88.3)\end{array}$ & $\begin{array}{l}-68.6 \\
(-92.2)\end{array}$ \\
\hline Osthole & $\begin{array}{c}-103.4 \\
(-119.3)\end{array}$ & $\begin{array}{c}-87.1 \\
(-100.5)\end{array}$ & $\begin{array}{l}-79.3 \\
(-91.5)\end{array}$ & $\begin{array}{l}-81.5 \\
(-94.0)\end{array}$ & $\begin{array}{l}-85.4 \\
(-98.6)\end{array}$ & $\begin{array}{c}-89.3 \\
(-103.0)\end{array}$ & $\begin{array}{l}-85.9 \\
(-99.1)\end{array}$ \\
\hline Pulegone & $\begin{array}{l}-71.8 \\
(-97.0)\end{array}$ & $\begin{array}{l}-63.6 \\
(-85.8)\end{array}$ & $\begin{array}{l}-43.4 \\
(-58.6)\end{array}$ & $\begin{array}{l}-57.3 \\
(-77.3)\end{array}$ & $\begin{array}{l}-59.0 \\
(-79.7)\end{array}$ & $\begin{array}{l}-69.1 \\
(-93.4)\end{array}$ & $\begin{array}{l}-70.6 \\
(-95.4)\end{array}$ \\
\hline trans- $\alpha$-Bergamotene & $\begin{array}{l}-74.9 \\
(-91.7)\end{array}$ & $\begin{array}{l}-65.4 \\
(-80.1)\end{array}$ & $\begin{array}{l}-67.2 \\
(-82.3)\end{array}$ & $\begin{array}{l}-68.6 \\
(-84.1)\end{array}$ & $\begin{array}{l}-62.9 \\
(-77.0)\end{array}$ & $\begin{array}{l}-81.5 \\
(-99.8)\end{array}$ & $\begin{array}{l}-68.2 \\
(-83.5)\end{array}$ \\
\hline Co-crystallized ligand & $\begin{array}{c}-142.7 \\
(-127.1)\end{array}$ & $\begin{array}{c}-137.2 \\
(-127.7)\end{array}$ & $\begin{array}{c}-105.6 \\
(-127.7)\end{array}$ & $\begin{array}{l}-162.0 \\
(-132.0)\end{array}$ & $\begin{array}{c}-147.8 \\
(-138.3)\end{array}$ & $\begin{array}{c}-97.2 \\
(-107.3)\end{array}$ & $\begin{array}{c}-129.2 \\
(-117.9)\end{array}$ \\
\hline
\end{tabular}




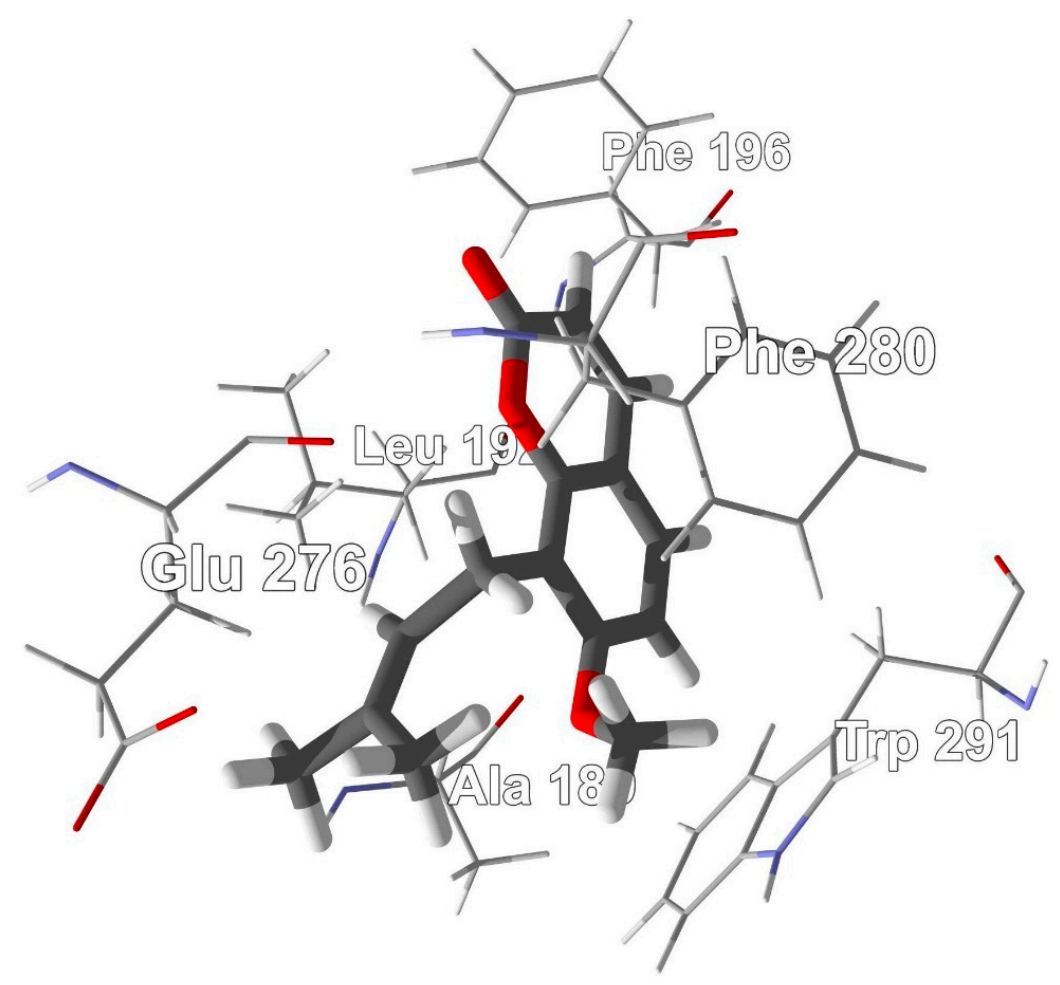

Figure 5. The allosteric binding site of human protein tyrosine phosphatase 1B (PTP-1B, PDB 1T48) with the lowest-energy docked pose of osthole.

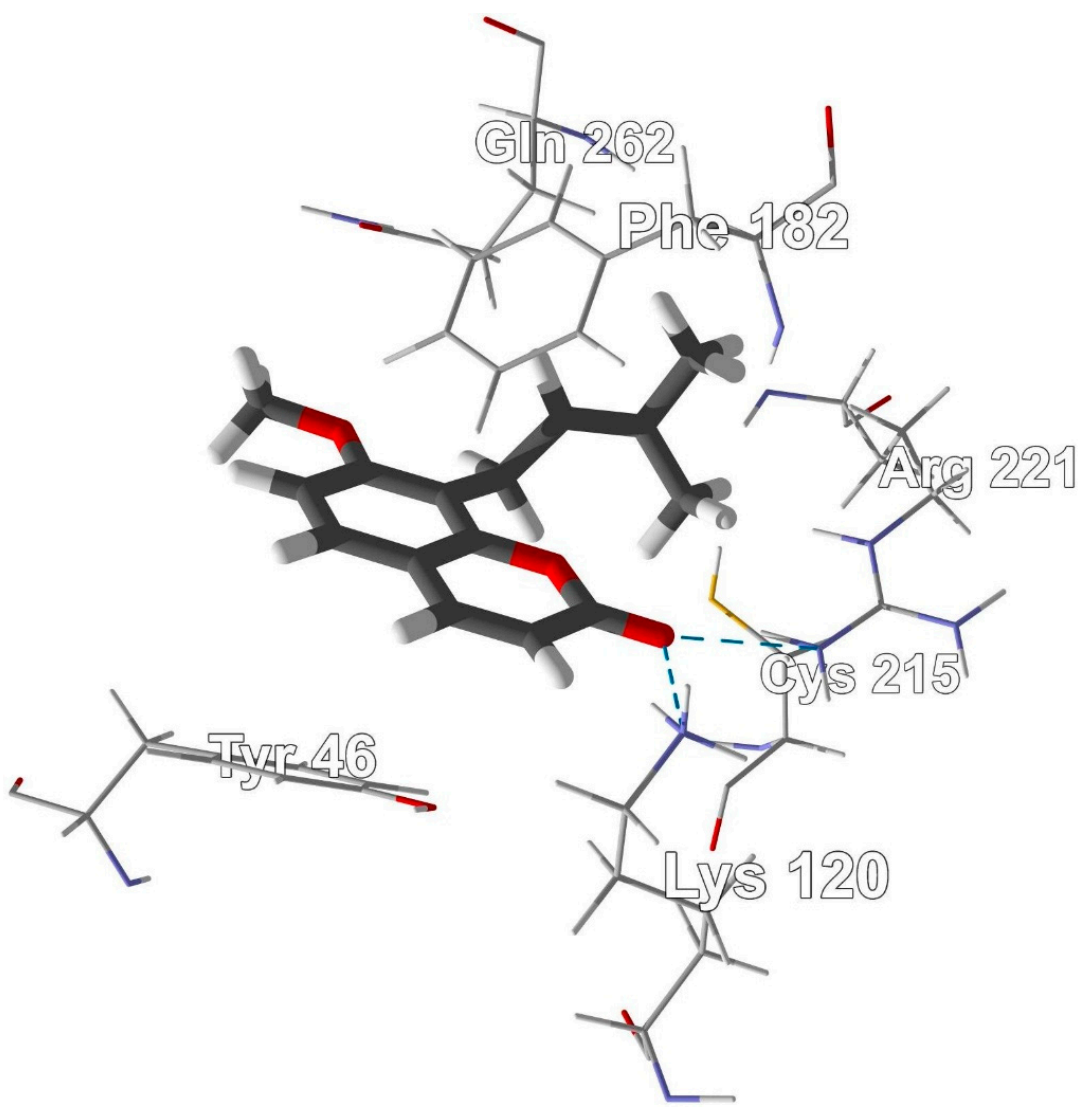

Figure 6. The active site of human protein tyrosine phosphatase $1 \mathrm{~B}$ (PTP-1B, PDB 2HB1) with the lowest-energy docked pose of osthole. Hydrogen-bonding interactions are indicated by the blue dashed lines. 
Ala and co-workers noted that " ... the active site of PTP-1B possesses very few desirable drug-design features" and that the highly charged portions of the active site " ... significantly increases the difficulty of designing potent inhibitors with acceptable membrane permeability" [55]. Thus, we conclude that the likely binding site for the P. pabularia essential oil components is the hydrophobic allosteric binding site, which is more consistent with the greater exothermic docking energies with the allosteric binding site (PDB 1T48, Figure 4B) than with the enzyme active site (Figure 4A). Furthermore, the docking energy for osthole is the most exothermic of the ligands examined, and this compound represents $6.0 \%$ of the essential oil composition.

The most abundant component, 5-pentylcyclohexa-1,3-diene (44.6\%), is a hydrocarbon, and although the docking energies are somewhat lower for the allosteric site than those for other essential oil components, the abundance of this compound may be a factor in the PTP-1B inhibitory activity of P. pabularia root essential oil. Wiesmann and co-workers pointed out that allosteric inhibitors “... prevent formation of the active form of the enzyme by blocking mobility of the catalytic loop" [56].

\section{Materials and Methods}

\subsection{Plant Material}

The roots of P. pabularia Lindl. were collected from the Yovon region $\left(3818^{\prime} 47^{\prime \prime} \mathrm{N}, 6902^{\prime} 35^{\prime \prime} \mathrm{E}\right.$ and $950 \mathrm{~m}$ above sea level) of Tajikistan in April 2017. The plant was authenticated by Doctor Farukh Sharopov, and the voucher sample (No. TAS 23659-1) was deposited in the herbarium of the Xinjiang Technical Institute of Physics and Chemistry Urumqi, Chinese Academy of Science. The air-dried sample was chopped into small pieces and hydrodistilled for $3 \mathrm{~h}$ to give the yellow essential oil with $0.1 \%$ yield. Osthole was isolated from the roots of Prangos pabularia by silica gel column (100-200 mesh) by elution of hexane ethyl acetate (20:1) [22].

\subsection{Gas Chromatography}

The quantification of the essential oil of $P$. pabularia was carried out by gas chromatography using Shimadzu GC-2010 (Shimadzu, Kyoto, Japan) plus gas chromatograph, non-polar Phenomenex ZB-5 fused bonded column ( $30 \mathrm{~m}$ length $\times 0.25 \mathrm{~mm}$ inner diameter and $0.25 \mu \mathrm{m}$ film thickness) and flame ionization detector (FID). Helium was the carrier gas, and the flow rate $=1.5 \mathrm{~mL} / \mathrm{min}$ with split mode. The following temperature program was used: Initial temperature $120^{\circ} \mathrm{C}$ held for $2 \mathrm{~min}$, temperature increased at a rate of $8{ }^{\circ} \mathrm{C} / \mathrm{min}$ until $320^{\circ} \mathrm{C}$ and then held for $10 \mathrm{~min}$ at $320^{\circ} \mathrm{C}$. Injector and detector and injector temperatures were $310^{\circ} \mathrm{C}$ and $320^{\circ} \mathrm{C}$, respectively. GC Solution software (version 2.53, Shimadzu, Kyoto, Japan) was used for recording and integration. The percentages of each component are reported as raw percentages based on peak area without standardization.

\subsection{Gas Chromatographic-Mass Spectral Analysis}

Compound identification of $P$. pabularia essential oil was carried out by gas chromatography-mass spectrometry using Agilent 6890 GC, Agilent 5973 (Agilent Technologies, Palo Alto, CA, USA) mass selective detector with electron ionization mass spectrometry (EIMS), (electron energy $=70 \mathrm{eV}$, scan range $=45-400 \mathrm{amu}$, and scan rate $=3.99 \mathrm{scans} / \mathrm{s})$, with HP-5ms capillary column $(30 \mathrm{~m}$ length $\times$ $0.25 \mathrm{~mm}$ inner diameter and $0.25 \mu \mathrm{m}$ phase thickness). Helium was the carrier gas with a flow rate of $1 \mathrm{~mL} / \mathrm{min}$. Oven temperature program: Hold at $40{ }^{\circ} \mathrm{C}$ for $10 \mathrm{~min}$, increase at $3^{\circ} \mathrm{C} / \mathrm{min}$ up to $200{ }^{\circ} \mathrm{C}$, and then increase at $2{ }^{\circ} \mathrm{C} / \mathrm{min}$ to $220^{\circ} \mathrm{C}$. The injector and the interface temperatures were $200{ }^{\circ} \mathrm{C}$ and $280{ }^{\circ} \mathrm{C}$, respectively. A $1 \% w / v$ solution of the essential oil in $\mathrm{CH}_{2} \mathrm{Cl}_{2}$ was prepared, and $1 \mu \mathrm{L}$ was injected with a splitless injection mode. Identification of the oil components was based on their Kovats indices determined by reference to a homologous series of $n$-alkanes and by comparison of their mass spectral fragmentation patterns with those reported in the literature (Adams 2007) and stored in the MS databases (NIST 17, WILEY 10, FFNSC versions 1.2, 2, and 3). 


\subsection{NMR and HR-ESIMS Analysis}

NMR spectra were recorded on a Varian MR-400 (400 MHz for ${ }^{1} \mathrm{H}$ and $100 \mathrm{MHz}$ for $\left.{ }^{13} \mathrm{C}\right)$ spectrometer (Palo Alto, CA, USA) in $\mathrm{CDCl}_{3}$. TMS ( $\delta 0.00$ ) signal was used as an internal standard for ${ }^{1} \mathrm{H}$ NMR shifts, and $\mathrm{CDCl}_{3}$ (77.160 ppm vs. TMS) signal was used as a reference for ${ }^{13} \mathrm{C}$ NMR shifts. The HR-ESIMS data were collected with a QStar Elite mass spectrometer (AB SCIEX, Framingham, MA, USA).

\subsection{Antidiabetic Activity: PTP-1B Enzymatic Assay}

The P. pabularia essential oil was screened for PTP-1B inhibition using pNPP ( $p$-nitrophenyl phosphate disodium salt) as the substrate. Both the essential oil sample and the enzyme were pre-incubated at room temperature for $5 \mathrm{~min}$ before use. A buffer solution (178 $\mu \mathrm{L}$ of $20 \mathrm{mM}$ HEPES, $150 \mathrm{mM} \mathrm{NaCl}$, and $1 \mathrm{mM}$ EDTA) was added to each well of a 96-well plate. The PTP-1B protein solution $(1 \mu \mathrm{L}$ at a concentration $0.115 \mathrm{mg} / \mathrm{mL})$ was added to the buffer solution, and then $1 \mu \mathrm{L}$ of the test solution and the positive control solution were added. The pNPP substrate ( $20 \mu \mathrm{L}$ of $35 \mathrm{mM}$ ) was added and mixed for $10 \mathrm{~min}$. The plate was incubated for $30 \mathrm{~min}$ in the dark, and the reaction then terminated by adding $10 \mu \mathrm{L}$ of $3 \mathrm{M} \mathrm{NaOH}$. The absorbance was then determined at $405 \mathrm{~nm}$ wavelength using a Spectra Max MD5 plate reader (Molecular Devices, USA). The system without the enzyme solution was used as a blank. Inhibition $(\%)=\left[\left(\mathrm{OD}_{405}-\mathrm{OD}_{405}\right.\right.$ blank $) / \mathrm{OD}_{405}$ blank $] \times 100$. The $\mathrm{IC}_{50}$ was calculated from the percent inhibition values.

\subsection{Molecular Docking}

Molecular docking of PTP-1B with the major components found in P. pabularia root essential oil was carried out on the X-ray crystal structures from the Protein Data Bank (PDB): 1T48, 1T49 [56], 2BGE [57], 2CMB [55], 2F71 [58], 2HB1 [59], and 3CWE [60]. The water molecules and the co-crystallized ligands were removed from the protein crystal structures. Molecular docking for the essential oil components with each of the protein structures was carried out using Molegro Virtual Docker, v. 6.0.1 (Molegro ApS, Aarhus, Denmark) as previously described [61]. A total of 12 major essential oil components were used in the docking study. The three-dimensional ligand structures were built using Spartan ' 18 for Windows, v. 1.2.0 (Wavefunction Inc., Irvine, CA, USA). For each docking simulation, a maximum of 1500 iterations with a maximum population size of 50 and 100 runs per ligand was carried out. MolDock re-rank scores were used to sort the poses generated for each ligand. In order to account for the bias toward high molecular weights, the following scheme was used: $\mathrm{DS}_{\text {norm }}=7.2 \times \mathrm{E}_{\mathrm{dock}} / \mathrm{MW}^{1 / 3}$, where $\mathrm{DS}_{\text {norm }}$ is the normalized docking score, $\mathrm{E}_{\text {dock }}$ is the MolDock re-rank score, MW is the molecular weight, and 7.2 is a scaling constant to bring the average $\mathrm{DS}_{\text {norm }}$ values comparable to $\mathrm{E}_{\text {dock }}[62]$.

\section{Conclusions}

This study reports the chemical profiles of the essential oils from the roots of P. pabularia containing 5-pentylcyclohexa-1,3-diene, menthone, 1-tridecyne, and osthole as major compounds. The high coumarin (osthole) content of the essential oil is particularly interesting in regard to the biological activities of the plant. Our investigations clarified the use of essential oil from the roots of P. pabularia for the development of formulations based on enzyme inhibition of PTP-1B. Based on molecular docking, we conclude that secondary volatile metabolites (especially osthole) are likely responsible for the inhibition of PTP-1B. Furthermore, the experimental data are also in agreement with the computational investigation. The anti-diabetic activity of essential oil is related to the dominant volatile compounds, which may be acting synergistically. Further confirmation of anti-diabetic activity of the essential oil from P. pabularia needs more research efforts (especially in vivo antihyperglycemic activity), which may be applied in food, agriculture, and medicinal industries as a source of anti-diabetic agent. 
Author Contributions: S.N., F.S.S., A.M., S.A. performed the phytochemical investigation, designed, and wrote the manuscript; W.N.S., F.S.S., S.N., A.S., M.B. analyzed data; W.N.S., S.N., M.S., M.H. studied the bio-pharmacological activities; H.A.A., W.N.S., made a critical revision of the manuscript.

Funding: The authors are grateful for financial support to the Chinese Academy of Sciences President's International Fellowship Initiative (Grant No. 2019PB0043), Central Asian Drug Discovery \& Development Center of Chinese Academy of Sciences (Grant No. CAM 201808), Foreign young scholar (Grant No. 2018FYB0004) and CAS “Light of West China” Program 2018-YDYLTD-001.

Acknowledgments: W.N.S. participated in this project as part of the activities of the Aromatic Plant Research Center (APRC, https://aromaticplant.org/).

Conflicts of Interest: The authors declare no conflict of interest.

\section{References}

1. WHO. About Diabetes; World Health Organization: Geneva, Switzerland, 2014.

2. International Diabetes Federation. IDF Diabetes Atlas; International Diabetes Federation: Brussels, Belgium, 2017.

3. Sharopov, F.S.; Zhang, H.; Wink, M.; Setzer, W.N. Aromatic medicinal plants from Tajikistan (Central Asia). Medicines 2015, 2, 28-46. [CrossRef] [PubMed]

4. Sharopov, F; Setzer, W.N. Medicinal plants of Tajikistan. In Vegetation of Central Asia and Environs; Egamberdieva, D., Öztürk, M., Eds.; Springer: Basel, Switzerland, 2018; pp. 163-210.

5. Sharopov, F. Phytochemistry and Bioactivities of Selected Plant Species with Volatile Secondary Metabolites. Ph.D. Thesis, University of Heidelberg, Heidelberg, Germany, 2015.

6. Yen, H.-F.; Hsieh, C.-T.; Hsieh, T.-J.; Chang, F.-R.; Wang, C.-K. In vitro anti-diabetic effect and chemical component analysis of 29 essential oils products. J. Food Drug Anal. 2015, 23, 124-129. [CrossRef] [PubMed]

7. Meshkani, R.; Taghikhani, M.; Al-Kateb, H.; Larijani, B.; Khatami, S.; Sidiropoulos, G.K.; Hegele, R.A.; Adeli, K. Polymorphisms within the protein tyrosine phosphatase 1B (PTPN1) gene promoter: Functional characterization and association with type 2 diabetes and related metabolic traits. Clin. Chem. 2007, 53, 1585-1592. [CrossRef] [PubMed]

8. Numonov, S.; Edirs, S.; Bobakulov, K.; Qureshi, M.N.; Bozorov, K.; Sharopov, F.; Setzer, W.N.; Zhao, H.; Habasi, M.; Sharofova, M.; et al. Evaluation of the antidiabetic activity and chemical composition of Geranium collinum root extracts-Computational and experimental investigations. Molecules 2017, 22, 983. [CrossRef] [PubMed]

9. Tonks, N.K.; Neel, B.G. Combinatorial control of the specificity of protein tyrosine phosphatases. Curr. Opin. Cell Biol. 2001, 13, 182-195. [CrossRef]

10. Bakke, J.; Haj, F.G. Protein-tyrosine phosphatase 1B substrates and metabolic regulation. Semin. Cell Dev. Biol. 2015, 37, 58-65. [CrossRef] [PubMed]

11. Venkataraghavan, R.; Brindha, P.; Ivo, R.S. A review on protein tyrosine phosphatases-an important target for various diseases. Asian J. Pharm. Clin. Res. 2018, 11, 11-16.

12. Florez, J.C.; Agapakis, C.M.; Burtt, N.P.; Sun, M.; Almgren, P.; Rastam, L.; Tuomi, T.; Gaudet, D.; Hudson, T.J.; Daly, M.J.; et al. Association testing of the protein tyrosine phosphatase 1B gene (PTPN1) with type 2 diabetes in 7,883 people. Diabetes 2005, 54, 1884-1891. [CrossRef] [PubMed]

13. Verma, M.; Gupta, S.J.; Chaudhary, A.; Garg, V.K. Protein tyrosine phosphatase 1B inhibitors as antidiabetic agents-A brief review. Bioorg. Chem. 2017, 70, 267-283. [CrossRef] [PubMed]

14. Jumaev, B.B.; Mirzoev, B.; Nigmonov, M.; Safarov, E.H.; Abdullaev, A.; Karimov, K.H. Physiological and biochemical characteristics leaf different layers of vegetative and generative shoots Prangos pabularia (Prangos pabularia Lindl.). Rep. Acad. Sci. Repub. Tajikistan 2014, 57, 695-700.

15. Sadikov, Y.J. Medicinal plant of Tajikistan. News Tajik Acad. Sci. 2003, 5, 41-48.

16. Razavi, S.M. Chemical composition and some allelopathic aspects of essential oils of (Prangos ferulacea L.) Lindl at different stages of growth. J. Agric. Sci. Technol. 2012, 14, 349-356.

17. Shokoohinia, Y.; Hosseinzadeh, L.; Alipour, M.; Mostafaie, A.; Mohammadi-Motlagh, H.-R. Comparative evaluation of cytotoxic and apoptogenic effects of several coumarins on human cancer cell lines: Osthole induces apoptosis in p53-deficient H1299 cells. Adv. Pharmacol. Sci. 2014, 2014, 8. [CrossRef] [PubMed]

18. Yousefi, K.; Hamedeyazdan, S.; Hodaei, D.; Fathiazad, F. An in vitro ethnopharmacological study on Prangos ferulacea: A wound healing agent. BioImpacts 2017, 7, 75-82. [CrossRef] 
19. Başer, K.H.; Demirci, B.; Demirci, F.; Bedir, E.; Weyerstahl, P.; Marschall, H.; Duman, H.; Aytaç, Z.; Hamann, M.T. A new bisabolene derivative from the essential oil of Prangos uechtritzii fruits. Planta Medica 2000, 66, 674-677. [CrossRef]

20. Özek, G.; Bedir, E.; Tabanca, N.; Ali, A.; Khan, I.A.; Duran, A.; Başer, K.H.C.; Özek, T. Isolation of eudesmane type sesquiterpene ketone from Prangos heyniae H.Duman \& M.F.Watson essential oil and mosquitocidal activity of the essential oils. Open Chem. 2018, 16, 453-467.

21. Tabanca, N.; Wedge, D.E.; Li, X.C.; Gao, Z.; Ozek, T.; Bernier, U.R.; Epsky, N.D.; Baser, K.H.; Ozek, G. Biological evaluation, overpressured layer chromatography separation, and isolation of a new acetylenic derivative compound from Prangos platychlaena ssp. platychlaena fruit essential oils. J. Planar Chromatogr.-Mod. TLC 2018, 31. [CrossRef]

22. Numonov, S.; Bobakulov, K.; Numonova, M.; Sharopov, F.S.; Setzer, W.N.; Khalilov, Q.; Begmatov, N.; Habasi, M.; Aisa, H.A. New coumarin from the roots of Prangos pabularia. Nat. Prod. Res. 2017, 32, 2325-2332. [CrossRef]

23. Ozek, G.; Ozek, T.; Iscan, G.; Baser, K.H.C.; Hamzaoglu, E.; Duran, A. Comparison of hydrodistillation and microdistillation methods for the analysis of fruit volatiles of Prangos pabularia Lindl., and evaluation of its antimicrobial activity. S. Afr. J. Bot. 2007, 73, 563-569. [CrossRef]

24. Tabanca, N.; Tsikolia, M.; Ozek, G.; Ozek, T.; Abbas, A.; Bernier, U.R.; Duran, A.; Baser, K.H.; Khan, I.A. The identification of suberosin from Prangos pabularia essential oil and its mosquito activity against Aedes aegypti. Rec. Nat. Prod. 2016, 10, 311-325.

25. Razavi, S.M. Chemical and allelopathic analyses of essential oils of Prangos pabularia Lindl. from Iran. Nat. Prod. Res. 2011, 26, 2148-2151. [PubMed]

26. Adams, R. Identification of Essential Oil Components by Gas Chromatography/Mass Spectrometry, 4th ed.; Allured Publishing Corp: Carol Stream, IL, USA, 2007.

27. Meshkatalsadat, M.H.; Bamoniri, A.; Batooli, H. The bioactive and volatile constituents of Prangos acaulis (DC) Bornm extracted using hydrodistillation and nanoscale injection techniques. Dig. J. Nanomater. Biostruct. 2010, 5, 263-266.

28. Sajjadi, S.E.; Mehregan, I. Chemical composition of the essential oil of Prangos asperula Boiss. subsp. haussknechtii (Boiss.) Herrnst. et Heyn fruits. DARU J. Pharm. Sci. 2003, 11, 23-28.

29. Mneimne, M.; Baydoun, S.; Nemer, N.; Apostolides, N.A. Chemical composition and antimicrobial activity of essential oils isolated from aerial parts of Prangos asperula Boiss. (Apiaceae) growing wild in Lebanon. Med. Aromat. Plants 2016, 5, 2-5.

30. Sajjadi, S.E.; Zeinvand, H.; Shokoohinia, Y. Isolation and identification of osthol from the fruits and essential oil composition of the leaves of Prangos asperula Boiss. Res. Pharm. Sci. 2009, 4, 19-23.

31. Lingan, K. A review on major constituents of various essential oils and its application. J. Transl. Med. (Sunnyvale) 2018, 8, 1000201. [CrossRef]

32. Baser, K.H.C.; Ermin, N.; Adigüzel, N.; Aytaç, Z. Composition of the essential oil of Prangos ferulacea (L.) Lindl. J. Essent. Oil Res. 2011, 8, 297-298. [CrossRef]

33. Massumi, M.A.; Fazeli, M.R.; Alavi, S.H.R.; Ajani, Y. Chemical constituents and antibacterial activity of essential oil of Prangos ferulacea (L.) Lindl. fruits. Iran. J. Pharm. Sci. 2007, 3, 171-176.

34. Delnavazi, M.R.; Soleimani, M.; Hadjiakhoondi, A.; Yass, N. Isolation of phenolic derivatives and essential oil analysis of Prangos ferulacea (L.) Lindl. aerial parts. Iran. J. Pharm. Res. 2017, 16, 207-215. [PubMed]

35. Ercan, S.F.; Bas, H.; Koc, M.; Pandir, D.; Öztemiz, S. Insecticidal activity of essential oil of Prangos ferulacea (Umbelliferae) against Ephestia kuehniella (Lepidoptera: Pyralidae) and Trichogramma embryophagum (Hymenoptera: Trichogrammatidae). Turkish J. Agric. For. 2013, 37, 719-725. [CrossRef]

36. Mohibi, Z.; Heshmati, G.A.; Sefidkon, F.; Chahouki, Z.M.A. The influence of plant growth satge, individuals of species, and extraction methods on the essential oil content and the chemical composition of Prangos ferulacea (L.) Lindl. Appl. Ecol. Environ. Res. 2017, 15, 1765-1776. [CrossRef]

37. Amiri, H. Chemical composition and antibacterial activity of essential oil of Prangos ferulacea (L.) Lindl. J. Med. Plants 2007, 1, 36-41.

38. Razavi, S.M.; Nazemiyeh, H.; Zarrini, G.; Asna-Asharii, S.; Dehghan, G. Chemical composition and antimicrobial activity of essential oil of Prangos ferulaceae (L.) Lindl from Iran. Nat. Prod. Res. 2009, 24, 530-533. [CrossRef] [PubMed] 
39. Başer, K.H.C.; Özek, T.; Demirci, B.; Duman, H. Composition of the essential oil of Prangos heyniae H. Duman et M. F. Watson, a new endemic from Turkey. Flavour Fragr. J. 2000, 15, 47-49. [CrossRef]

40. Kiliç, Ö.; Bengü, A.Ş.; Özdemir, F.A.; Çelik, Ş. Essential oil composition of two Prangos Lindl. (Apiaceae) species from Turkey. Prog. Nutr. 2017, 19, 69-74.

41. Abolghasemi, M.M.; Piryaei, M. Fast determination of Prangos uloptera essential oil by nanoporous silica-polypyrrole SPME fiber. Chemija 2012, 23, 244-249.

42. Sefidkon, F.N. Chemical composition of the oil of Prangos uloptera DC. J. Essent. Oil Res. 2001, 13, 84-85. [CrossRef]

43. Alikhah-Asl, M.; Azarnivand, H.; Jafari, M.; Arzani, H.; Amin, G.; Zare-Chahouki, M.A. Variations of essential oils in fresh and dried aerial parts of Prangos uloptera. J. Nat. Prod. 2012, 5, 5-9.

44. Hayta, Ş. Essential oil composition of the fruit of Prangos uloptera (Apiaceae) DC. from Turkey. Pharm. Chem. J. 2018, 5, 1-5.

45. Figueroa, M.; Rivero-Cruz, I.; Rivero-Cruz, B.; Bye, R.; Navarrete, A.; Mata, R. Constituents, biological activities and quality control parameters of the crude extract and essential oil from Arracacia tolucensis var. multifida. J. Ethnopharmacol. 2007, 113, 125-131. [CrossRef]

46. Wang, H.; Gu, D.; Wang, M.; Guo, H.; Wu, H.; Tian, G.; Li, Q.; Yang, Y.; Tian, J. A strategy based on gas chromatography-mass spectrometry and virtual molecular docking for analysis and prediction of bioactive composition in natural product essential oil. J. Chromatogr. A 2017, 1501, 128-133. [CrossRef]

47. Saifudin, A.; Tanaka, K.; Kadota, S.; Tezuka, Y. Chemical constituents of Blumea balsamifera of Indonesia and their protein tyrosine phosphatase 1B inhibitory activity. Nat. Prod. Commun. 2012, 7, 815-818. [CrossRef]

48. Wu, W.B.; Huan, Z.; Dong, S.; Yue, M. New triterpenoids with protein tyrosine phosphatase 1B inhibition from Cedrela odorata. Asian Nat. Prod. Res. 2014, 16, 1-8. [CrossRef]

49. Bharti, S.K.; Kumar, A.; Prakash, O.; Krishnan, S.; Gupta, A.K. Essential oil of Cymbopogon citratus against diabetes: Validation by in vivo experiments and computational studies. J. Bioanal. Biomed. 2013, 5, $194-203$.

50. Zhang, Z.-R.; Leung, W.N.; Cheung, H.Y.; Chan, C.W. Osthole: A review on its bioactivities, pharmacological properties, and potential as alternative medicine. Evid.-Based Complement. Altern. Med. 2015, 2015, 919616. [CrossRef]

51. Liang, H.-J.; Suk, F.-M.; Wang, C.-K.; Hung, L.-F.; Liu, D.-Z.; Chen, N.-Q.; Chen, Y.-C.; Chang, C.-C.; Liang, Y.-C. Osthole, a potential antidiabetic agent, alleviates hyperglycemia in db/db mice. Chem.-Biol. Interact. 2009, 181, 309-315. [CrossRef]

52. Lee, W.-H.; Lin, R.-J.; Lin, S.-Y.; Chen, Y.-C.; Lin, H.-M.; Liang, Y.-C. Osthole enhances glucose uptake through activation of AMP-activated protein kinase in skeletal muscle cells. J. Agric. Food Chem. 2011, 59, 12874-12881. [CrossRef]

53. Yao, Y.; Zhao, X.; Xin, J.; Wu, Y.; Li, H. Coumarins improved type 2 diabetes induced by high-fat diet and streptozotocin in mice via antioxidation. Can. J. Physiol. Pharm. 2018, 96, 765-771. [CrossRef]

54. Thomsen, R.; Christensen, M.H. MolDock: A New Technique for High-Accuracy Molecular Docking. J. Med. Chem. 2006, 49, 3315-3321. [CrossRef]

55. Ala, P.J.; Gonneville, L.; Hillman, M.C.; Becker-Pasha, M.; Wei, M.; Reid, B.G.; Klabe, R.; Yue, E.W.; Wayland, B.; Douty, B.; et al. Structural basis for inhibition of protein-tyrosine phosphatase $1 \mathrm{~B}$ by isothiazolidinone heterocyclic phosphonate mimetics. J. Biol. Chem. 2006, 281, 32784-32795. [CrossRef]

56. Wiesmann, C.; Barr, K.J.; Kung, J.; Zhu, J.; Erlanson, D.A.; Shen, W.; Fahr, B.J.; Zhong, M.; Taylor, L.; Randal, M.; et al. Allosteric inhibition of protein tyrosine phosphatase 1B. Nat. Struct. Mol. Biol. 2004, 11, 730-737. [CrossRef]

57. Black, E.; Breed, J.; Breeze, A.L.; Embrey, K.; Garcia, R.; Gero, T.W.; Godfrey, L.; Kenny, P.W.; Morley, A.D.; Minshull, C.A.; et al. Structure-based design of protein tyrosine phosphatase-1B inhibitors. Bioorg. Med. Chem. Lett. 2005, 15, 2503-2507. [CrossRef]

58. Klopfenstein, S.R.; Evdokimov, A.G.; Colson, A.-O.; Fairweather, N.T.; Neuman, J.J.; Maier, M.B.; Gray, J.L.; Gerwe, G.S.; Stake, G.E.; Howard, B.W.; et al. 1,2,3,4-Tetrahydroisoquinolinyl sulfamic acids as phosphatase PTP1B inhibitors. Bioorganic Med. Chem. Lett. 2006, 16, 1574-1578. [CrossRef]

59. Wan, Z.-K.; Lee, J.; Xu, W.; Erbe, D.V.; Joseph-McCarthy, D.; Follows, B.C.; Zhang, Y.-L. Monocyclic thiophenes as protein tyrosine phosphatase $1 \mathrm{~B}$ inhibitors: Capturing interactions with Asp48. Bioorg. Med. Chem. Lett. 2006, 16, 4941-4945. [CrossRef] 
60. Han, Y.; Belley, M.; Bayly, C.I.; Colucci, J.; Dufresne, C.; Giroux, A.; Lau, C.K.; Leblanc, Y.; McKay, D.; Therien, M.; et al. Discovery of [(3-bromo-7-cyano-2-naphthyl)(difluoro)methyl]phosphonic acid, a potent and orally active small molecule PTP1B inhibitor. Bioorg. Med. Chem. Lett. 2008, 18, 3200-3205. [CrossRef]

61. Byler, K.G.; Ogungbe, I.V.; Setzer, W.N. In-silico screening for anti-Zika virus phytochemicals. J. Mol. Graph. Model. 2016, 69, 78-91. [CrossRef]

62. Setzer, M.S.; Byler, K.G.; Ogungbe, I.V.; Setzer, W.N. Natural products as new treatment options for trichomoniasis: A molecular docking investigation. Sci. Pharm. 2017, 85, 5. [CrossRef]

C 2019 by the authors. Licensee MDPI, Basel, Switzerland. This article is an open access article distributed under the terms and conditions of the Creative Commons Attribution (CC BY) license (http://creativecommons.org/licenses/by/4.0/). 